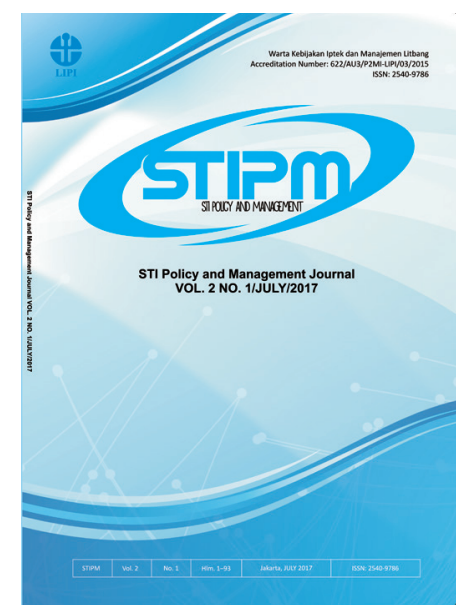

Journal of STI Policy and Management

Publication details, including instructions for authors and subscription information: http://www.stipmjournal.org/

\title{
Interactive Learning for Upgrading and Growth: Case of Indonesian Fishery Firms
}

\section{Erman Aminullah, Trina Fizzanty, Karlina Sari, Rizka Rahmaida, and Qinan M.B. Soesanto}

Indonesian Institute of Sciences (LIPI), Jakarta

Version of record first published: 15 July 2017

To cite this article: Aminullah, E., Fizzanty, T., Sari, K., Rahmaida, R., and Soesanto, Q.M.B. (2017). Interactive Learning for Upgrading and Growth: Case of Indonesian Fishery Firms. Journal of STI Policy and Management, $2(1), 29-42$

To link to this article: http://dx.doi.org/10.14203/STIPM.2017.115

ISSN 2540-9786 (Print); ISSN 2502-5996 (online)

Accreditation Number: 622/AU3/P2MI-LIPI/03/2015

Full terms and conditions of use: https://creativecommons.org/licenses/by-nc-sa/4.0/

You are free to:

- Share $\quad$ : copy and redistribute the material in any medium or format

- Adapt : remix, transform, and build upon the material

- The licensor cannot revoke these freedoms as long as you follow the license terms.

Under the following terms:

Attribution - You must give appropriate credit, provide a link to the license, and indicate if changes were made. You may do so in any reasonable manner, but not in any way that suggests the licensor endorses you or your use.

NonCommercial - You may not use the material for commercial purposes.

ShareAlike - If you remix, transform, or build upon the material, you must distribute your contributions under the same license as the original.

No additional restrictions - You may not apply legal terms or technological measures that legally restrict others from doing anything the license permits.

Notices:

- You do not have to comply with the license for elements of the material in the public domain or where your use is permitted by an applicable exception or limitation.

- No warranties are given. The license may not give you all of the permissions necessary for your intended use. For example, other rights such as publicity, privacy, or moral rights may limit how you use the material.

- If you copy the dataset merely to extract the uncopyrightable data elements would not need permission to do so. However, if you republish the full dataset or using the copyrightable data layers require a permission from PAPPIPTEK-LIPI. 


\title{
JOURNAL OF SCIENCE, TECHNOLOGY AND INNOVATION POLICY AND MANAGEMENT (STIPM JOURNAL), Volume 02, Number 01, July 2017
}

\author{
FOREWORD by EDITOR-in-CHIEF
}

We are very pleased to inform readers that Journal of Science, Technology and Innovation Policy and Management (STIPM Journal) Vol. 2, No. 1, July 2017 is now ready for public reading.

The STIPM Journal is an online research journal managed by the Center for Science and Technology Development Studies at the Indonesian Institute of Sciences (PAPPIPTEK-LIPI). As a peer-reviewed journal, the STIPM Journal provides free access to research thoughts, innovation, and original discoveries mostly aimed at scholars.

In this edition, the STIPM Journal contains six articles dealing with science, technology and innovation policy and management written by scholars from Japan, Australia, and Indonesia.

The first article is entitled "Innovation Process of Natural Resource-based Firms in Four ASEAN Economies: A SEM Approach" by Masatsugu Tsuji, Hiroki Idota, Yasushi Ueki, and Teruyuki Bunno. Using a structural equation model (SEM), this paper discusses the innovation process in natural resourcebased industries in Vietnam, Indonesia, the Philippines, and Thailand in comparison to other assembling and processing industries by focusing how factors affect product as well as process innovation.

The second article is written by Noel Taylor-Moore, entitled "The Innovative Policy Options for Coastal Fisheries Economic Development: A Case of Kwandang Bay Coastal Ecosystem”. This article uses a policy innovation framework in the context of STI inputs and a multi-level perspective (MLP), selects a potential site in which a fisheries economic development hub would be implemented, and performs a SWOT analysis of the selected site as a hub.

Erman Aminullah, Trina Fizzanty, Karlina Sari, Rizka Rahmaida, and Qinan M. B. Soesanto present the third article, "Interactive Learning for Upgrading and Growth: Case of Indonesian Fishery Firms." This article discusses an interactive learning model for upgrading and growth in Indonesian fishery firms using the case of fish processing and aquaculture (shrimp). The model suggests that the dynamics of upgrading and growth through interactive learning will be able to continue in a stable manner as constraints from limiting elements are eased through: combating illegal fishing; encouraging interaction with universities; shifting to higher added-value products; increasing institutional support for global trading; preventing shrimp diseases; and providing infrastructure, business facilities, and regulation information.

The fourth article, entitled "Developing the Marine and Fisheries Industry in Pangandaran using a Bioecoregion-based Technopark Framework", is written by Atikah Nurhayati and Agus H. Purnomo. This article discusses how to establish a marine and fisheries technopark in Pangandaran. By using gap and SWOT analysis, it was found that particular recommendations for improvement should be made, 
the existing bioecoregional environment and development variables in Pangandaran would support the development of a marine and fisheries technopark.

The fifth article, entitled "Development of National Technology Audit Policy", is presented by Subiyanto. This article discusses the concept of a national technology auditing policy, particularly with regard to infrastructure requirements, and with emphasis on technical regulation effectiveness and implementation tool readiness. This article discusses setting a policy agenda by discussing the governance aspect of national technology auditing.

The final article is written by Anugerah Yuka Asmara and Toshio Mitsufuji with the title "Photovoltaic Development from the New Order Era to the Reform Era in Indonesia: From a Technological Innovation System Perspective”. This article discusses the phenomena of PV development between the New Order era and the Reform era using a technological innovation system (TIS) approach. This paper concludes that PV projects and technology could not be developed en masse without intervention from the government in both the New Order era and the Reform era.

We also would like to thank the authors, editors, and reviewers who have worked very hard for this edition. We hope that all the articles featured in this edition proves useful to the reader.

Jakarta, 16 July 2017

Editor-in-Chief 



\section{JOURNAL OF STI POLICY AND MANAGEMENT}

Volume 2, Number 1, July 2017

\section{LIST OF CONTENTS}

Innovation Process of Natural Resource-based Firms in Four ASEAN Economies: A SEM Approach

Masatsugu Tsuji, Hiroki Idota, Yasushi Ueki, and Teruyuki Bunno

The Innovative Policy Options for Coastal Fisheries Economic Development: A Case of Kwandang

Bay Coastal Ecosystem

Noel Taylor-Moore

Interactive Learning for Upgrading and Growth: Case of Indonesian Fishery Firms

Erman Aminullah, Trina Fizzanty, Karlina Sari, Rizka Rahmaida, and Qinan M.B. Soesanto

Developing the Marine and Fisheries Industry in Pangandaran using a Bioecoregion-based Technopark Framework

Atikah Nurhayati and Agus Heri Purnomo

Development of National Technology Audit Policy

Subiyanto.

Photovoltaic Development from the New Order Era to the Reform Era in Indonesia:

From a Technological Innovation System Perspective

Anugerah Yuka Asmara and Toshio Mitsufuji. 


\title{
if STI POLICY AND MANAGEMENT

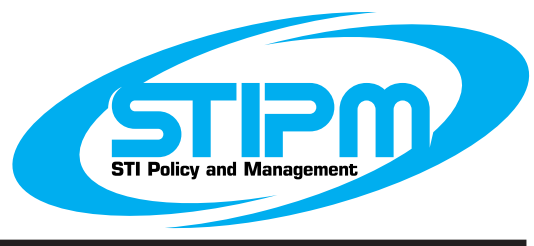

\section{Interactive Learning for Upgrading and Growth: Case of Indonesian Fishery Firms}

\author{
Erman Aminullah, Trina Fizzanty, Karlina Sari, Rizka Rahmaida, Qinan M.B. Soesanto \\ Indonesian Institute of Sciences (LIPI), Jakarta
}

\begin{tabular}{|c|c|}
\hline ARTICLE INFO & ABSTRACT \\
\hline $\begin{array}{l}\text { Article History: } \\
\text { Received : } 29 \text { May } 2017 \\
\text { Revised : 09 July } 2017 \\
\text { Accepted : 10 July } 2017 \\
\text { Available online : } 15 \text { July } 2017\end{array}$ & $\begin{array}{l}\text { This paper intends to reveal the interactive learning for upgrading } \\
\text { and growth in Indonesian fishery firms. The main question is how } \\
\text { learning and innovation have occurred in Indonesian fishery firms. } \\
\text { The study was conducted in two categories of fishery firms: fish } \\
\text { processing and aquaculture (shrimp). The interfirm interactions }\end{array}$ \\
\hline $\begin{array}{l}\text { Keywords: } \\
\text { Upgrading } \\
\text { Growth } \\
\text { Limiting elements } \\
\text { Knowledge flows } \\
\text { Production network } \\
\text { Global market }\end{array}$ & $\begin{array}{l}\text { contain knowledge flows and feedback in local production network } \\
\text { involving local suppliers and foreign buyers. The study found } \\
\text { that the model of interactive learning for upgrading and growth } \\
\text { works as a coupling of three loops: the upgrading capability, the } \\
\text { growth formation, and limiting elements. The upgrading capability } \\
\text { is subject to growth formation, which is determined by limiting } \\
\text { elements. The limiting elements will control the quantity and } \\
\text { quality of materials supply that affect inter-firm interaction. The } \\
\text { model suggests that the dynamics of upgrading and growth through } \\
\text { interactive learning will continue in a stable manner by easing the } \\
\text { constraints of limiting elements through: combating illegal fishing, } \\
\text { encouraging interaction with universities, shifting to higher added } \\
\text { value products, institutional support for global trading, preventing } \\
\text { shrimp disease, providing infrastructure, business facilities, and } \\
\text { regulation information. }\end{array}$ \\
\hline
\end{tabular}

(C2017 PAPPIPTEK-LIPI All rights reserved

\section{INTRODUCTION}

\section{A. Background and objective}

There has been much previous research about fishery in the body of literature, including research on innovation in Indonesian fish commodities and products, such as i) research related to quality of fish and added value in fish processing that affects Indonesian fish products for the export market (van Duijn, 2012); ii) the relative weakness of

\footnotetext{
* Corresponding Author.

E-mail: trinafizz@gmail.com
}

export competitiveness of Indonesian fishery products in the processing of added value products (Saptanto, 2011); iii) the important role of research results as input for the decision-making in fisheries policy in Indonesia (Asmara, 2012); iv) the increase of seafood productivity (shrimp) associated with research budget in shrimp, providing seed quality and human resource capacity building (Juarno, 2011). Other related studies on innovation in seafood industry are: innovation and quota management system (Jeffs, n.d.), 
governance of industrial policy and innovation system (Aslesen, 1999), and production change and innovation system (Gonzalez-Lopez, 2012).

Fishery firms continually upgrade technological and organizational requirements, otherwise the firms will be uncompetitive and losing its foreign buyers in global market. For the firms to operate in a global market, upgrading means creating better products, more efficient process, and more skilled activities through interfirm knowledge flows. The role of entrepreneur is also important, as the driver for company to learn, shift, and grow in global business. It can be: i) learned global is a leading to global business slowly by learning from the experience and accumulated knowledge; ii) global born is an integration to global in a short time since it was founded immediately go global; iii) and born-again global domestic company suddenly gone global after shock or triggered by critical events' (Mets, 2012).

Entrepreneurs have important role in upgrading firms' technological and organizational requirements. The general capabilities of entrepreneurs are risk taking, pro-activeness and innovativeness as well as clear orientation. The specific capability of entrepreneur is always alert to new international market opportunities because of their knowledge and learning acquired from earlier activities (Zucchella \& Scabini, 2007). Entrepreneurs build and maintain relevant, superior and effective networks including social networks, which provide both information and trust to manage risk in global business (Casson, 2010). Entrepreneurial networks are vital in discovering opportunities, testing ideas, and garnering resources for the formation of the new organizational structures (Weerawardena, Mort, Liesch, \& Knight, 2007). Then, the entrepreneurial networks exist and work in a global distribution chains under buyer-producer relationship (Nicita, Ognivtsev, \& Shirotori, 2013).

The governance of fish product value chains is mainly led by buyers/retailers and branded processors. In the value chain of shrimps, the governance of relations between governments in importing and exporting countries as well as between importer and NGOs are basically buyer-driven (Tran, 2013). Meanwhile, the governance of seafood value chains is supported by the quality of domestic institutional framework that facilitates the compliance to the standards demanded by international buyers (Jespersen, Kellings, Ponte, \& Kruijsse 2014). Local suppliers/shrimp farmers upgrade their production to meet the standard required for international market by facilitating horizontal coordination between producers' clusters. However, the success of a cluster depends on the effectiveness of vertical coordination with other actors along the value chain for both the provision of inputs and the marketing of outputs (Ha, Bush, \& van Dijk, 2013). Innovation of switching the shrimp species from the culture of black tiger shrimp (Penaeus monodon) to pacific white shrimp (Litopenaeus vannamei) will increase the competitiveness of shrimp culture industry. Innovation that rears white shrimp requires less resource and produces less waste than black shrimp (Lebel, Munkung, Gheewala, \& Lebel 2010).

Together with applying innovate governance in operating within the GVC, shrimp processing firms have to upgrade technological and organizational requirements to respond the strict rules and regulations of food safety and quality assurance imposed by the importing countries (Alam \& Pokrant, 2009; Sari, Arifin, Octaviyanti, Kusnandar, \& Syahbana, 2014). The quality of shrimp is also sensitive to shrimp disease and pollution. In Vietnam, the pollution was due to the open access of water ignited by the over intensification of shrimp production (Truong, Lyne, \& Ford, 2014). In India, promotional measures by the government were the major causes for the uncontrolled growth of the industry and led to the accumulation of pollution (Prusty, Pratap, Mohapatra, \& Mukherjee, 2014). In Indonesia, the pollution was ignited by a mud volcano, which affected irrigation and water quality (Fitrianto, 2012).

Moreover, managing the shrimp industry as a cluster with environmental friendly methods is decisive for shrimp quality. The cluster will require the participation among economic, policy and social networks to implement the concept of industrial ecology through cleaner production (Anh, Dieu, Moi, Kroeze, \& Bush, 2011). 
In ensuring food safety and quality standards, the implementation of multilayered conformity assessment system (MCAS) is globally adopted to produce chemical-free shrimp products (Hatanaka, 2014).

While abundant literature on upgrading and growth in fishery sector is a given availability, the study of linking upgrading and growth as a whole entity will contribute to enrich the current body of literature on innovation studies in fishery sector. This paper intends to reveal the dynamics of upgrading and growth in Indonesian fishery firms. The main question is how learning and innovation have occured in Indonesian fishery firms. The more specific questions are: i) how varieties of products, processes, and services innovation take place inside the firms as viewed from knowledge flows among interactive firms, i.e., buyers, producers, and suppliers; ii) how knowledge flows bring to the dynamic of upgrading and growth in Indonesian fishery firms; and iii) what industrial and innovation policies affect the dynamic of upgrading and growth in Indonesian fishery firms.

\section{B. Method of study}

This case study was developed from the results of previous case study in fishery firms. The selected firms comprised of two categories: fish processing firms and aquaculture (shrimp). One firm was engaged in fish processing and aquaculture (A/A"), two in fish processing (B, C), and two were aquaculture firms $(\mathrm{D}, \mathrm{E})$. The firms were chosen because they are: i) firms which have a global distribution or export market, and ii) firms which represent either medium or largescale company categories. The study utilized the combining information from two previous case studies by Aminullah, Fizzanty, Indraprahasta, \& Asmara (2015a) and Aminullah, Sari, Rahmaida, \& Soesanto, Q.M.B (2015b). This case study is different from the previous two studies in terms of its analytical framework. Establishing a new analytical framework as the lens for analyzing the existing information will contribute to enrich existing models of innovation studies in fishery sector. Aminullah, et. al. (2015b) argues that the new model of interactive learning for upgrading and growth is validated by empirical evidence in fishery sector is a scientific contribution of this study.

\section{FIRMS' INTERACTION IN PRODUCTION NETWORK FOR EXPORT MARKET: ANALYTICAL FRAMEWORK}

Firms interaction in production network for export market here refers to interactions among firms in production network to grow in line with the business and service innovation to upgrade the product towards export market. The interaction involves three main actors, namely local supplier, local producer, and foreign buyer. The local producer upgrades the knowledge on technical competence in meeting the various standards set by foreign buyer. The local producer transmits the technical competence needed for local supplier and farming. The supplier sends fish commodity according to standards set by local producer. Finally, the local producer delivers the standardized fish product demanded by foreign buyer (Aminullah et. al, 2015b).

The foreign buyer provides information on standard needs related to product quality, processing technology, and the certified product. Types of information feedback from local producer to foreign buyer/supplier include the specifications of product quality and quantity. Furthermore, types of knowledge flows from a local producer to local supplier/farming include mortality control, water management, water quality, health of seed growth maintenance, and species diversification. Types of information feedback from local supplier/farming to local producer are as follows: register of traceability, chemical residue free, and organoleptic standards. The integrated knowledge flows and information feedback will help firms to increase production and change into a higher value chain by promoting product, process, and organizational innovation (See Figure 1).

The success of upgrading is driven by the buyer-producer relationship. The buyer-producer relationship induces the user-dominated innovation, through which the producer gains knowledge from the buyer in producing the certain product for export. The concept of upgrading refers to several types of shifts that firms or group of firms might 


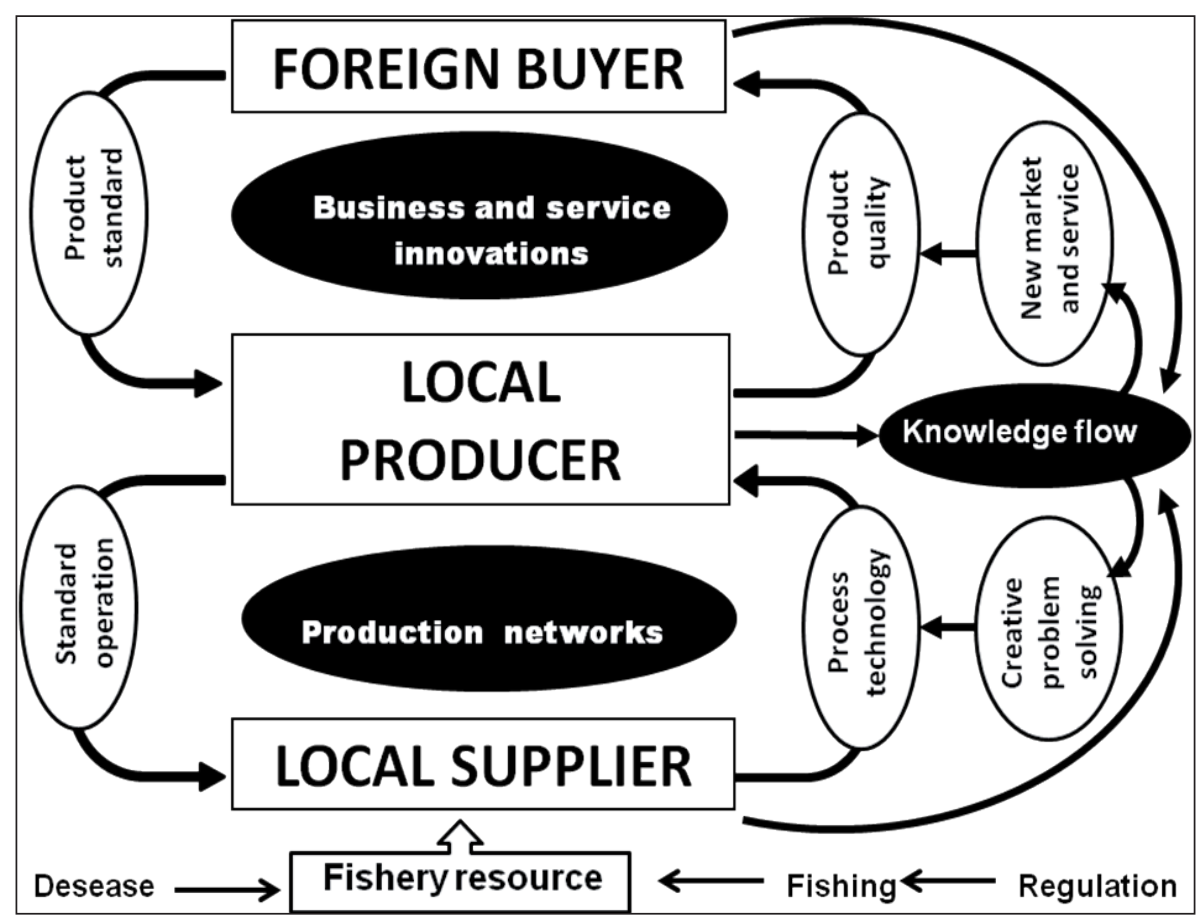

Sources: adapted from Aminullah, et al. (2015b)

Figure 1. Firms' Interaction in Production Network for Export Market

undertake to improve their competitive position in GVCs. According to Humphrey and Schmitz (2000) and Gereffi, Humphrey, Kaplinsky, \& Sturgeon (2001), there are four types of upgrading: product, process, intrachain, and interchain upgradings. ${ }^{1}$ Such categories of upgrading exist generally in fishery firms, while upgrading in aquaculture also involves the implementation of different managerial models, supplying different

The authors' interpretation about types of upgrading in fishery sector are as follows. i) Product upgrading: fishery firms can upgrade by moving into more sophisticated product lines, which can be defined in terms of increased unit values. ii) Process upgrading: fishery firms can upgrade processes by transforming inputs into outputs more efficiently through superior technology or reorganizing the production systems. iii) Intra-chain upgrading: this involves several types of upgrading opportunities that exist within a particular value chain. Firms can acquire new functions in the chain, move backward or forward to different stages in a value chain, and diversify their buyer-supplier linkages within a value chain. iv) Inter-chain upgrading: this occurs when fishery firms apply the competence acquired in a particular function of a chain (e.g. competence in producing particular inputs or in export marketing) to a new sector. end markets, improving efficiency, and meeting social and environmental standards without necessarily increasing the value of products (Ponte, Kellings, Jespersen, \& Kruijsse, 2014).

The success of growth is driven by the supplier-producer relationship. The supplierproducer relationship determines the quantity and quality of production demanded by foreign buyers or the export market. The production network facilitates pathways toward export market for global oriented fishery firms. The growth of firms to become global firms can be categorized as: global born directly, fast learned global, and delay learned global firms (Aminullah, 2015a, Graph 2). The trigger of firm growth in becoming a global market player is not only influenced by the specific capabilities of the entrepreneur in exploring new international market opportunities, but also determined by the availability of fishery resources which is subject to regulation on overfishing and illegal fishing as well as shrimp disease in aquaculture sector. 


\section{UPGRADING AND GROWTH IN FISHERY FIRMS: CASE STUDY FINDINGS}

\section{A. Dynamics of upgrading}

The dynamics of upgrading here refers to a change in firms' capabilities involving three main actors, namely local supplier, local producer, and foreign buyer. The upgrading of the firm's knowledge on technical competence are caused by changing the patterns of interactions among buyer, producer, supplier, and competitor as described in Table 1.

\section{Firm $A$}

Tighter competition in the export market leads to product diversification, which leads to higher added value. Firm A began producing frozen shrimp processing in 2001. In the beginning, Firm A was only exporting frozen shrimp on demand from importing countries. Firm A produces frozen shrimp in various forms, which are more attractive in Japan than in the US and European markets. Since 2004, it has been producing a variety of processed shrimp products, which added a higher value as a response to a tighter competition in the export market of frozen shrimp. In marketing its products, Firm A has sold its own brand of products for the purpose of export and for selling in domestic supermarkets. Currently, the firm produces value-added shrimp products with various brands. There is also a value-added product in the form of ready-to-eat for domestic markets.

A change in market taste leads to increase in product upgrading. The firm actively explores some idea of innovation from external sources through monitoring the progress of innovation by similar companies abroad. The firm's executives and its R\&D units follow the trends and development of the seafood industry products abroad; it is a part of Firm A's observation on a change in market tastes. This information is used by the firm to identify the opportunities of developing its own products in the country. Its R\&D unit also conducts experiments that are useful for developing various high quality products, especially value-added products.

An increase in global competition causes the performance of intra-chain upgrading. Firms have been successful in diversifying its buyer-supplier linkages within a value chain; for instance, market diversification through product

Table 1.

Dynamics of Upgrading in Fishery Firms

\begin{tabular}{|c|c|c|c|c|c|}
\hline $\begin{array}{c}\text { Business } \\
\text { area }\end{array}$ & Firm & $\begin{array}{l}\text { Business } \\
\text { system }\end{array}$ & $\begin{array}{l}\text { Types of } \\
\text { upgrading }\end{array}$ & DYNAMICS OF UPGRADING & Patterns of interactions \\
\hline \multirow{3}{*}{ 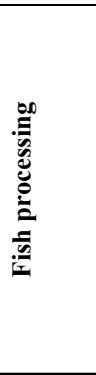 } & $\mathbf{A}$ & $\begin{array}{l}\text { Diversified } \\
\text { business }\end{array}$ & $\begin{array}{l}\text { Product } \\
\text { and intra- } \\
\text { chain } \\
\text { upgrading }\end{array}$ & $\begin{array}{l}\text {-Tighter competition in export market lead to product diversification which } \\
\text { have higher added value. } \\
\text { - A change in market taste leads to increases in product upgrading } \\
\bullet \text { An increase in global competition causes the performance of intra-chain } \\
\text { upgrading }\end{array}$ & $\begin{array}{l}\text { Producer's knowledge on } \\
\text { competitor } \\
\text { Buyer-producer relationship }\end{array}$ \\
\hline & B & $\begin{array}{l}\text { Integrated } \\
\text { busines }\end{array}$ & $\begin{array}{l}\text { Product } \\
\text { and intra- } \\
\text { chain } \\
\text { upgrading }\end{array}$ & $\begin{array}{l}\text { - Customer demand on product quality requires firms to strictly apply } \\
\text { product and process standardization } \\
\text { - A change in user's requirements leads to increases in product upgrading } \\
\text { - An increase in market demand for export causes the performance of } \\
\text { intra-chain upgrading }\end{array}$ & Buyer-producer relationship \\
\hline & $\mathbf{C}$ & $\begin{array}{l}\text { Specialized } \\
\text { business }\end{array}$ & $\begin{array}{l}\text { Product } \\
\text { upgrading }\end{array}$ & $\begin{array}{l}- \text { An increase in material shortage leads to a shift toward alternative } \\
\text { sources of material } \\
- \text { A change in buyer's requirements leads to increases in product upgrading }\end{array}$ & $\begin{array}{l}\text { Buyer-producer relationship } \\
\text { Supplier-producer relationship }\end{array}$ \\
\hline \multirow{3}{*}{ 冚 } & A" & $\begin{array}{l}\text { Integrated } \\
\text { business }\end{array}$ & $\begin{array}{l}\text { Intrachain } \\
\text { \& } \\
\text { Interchain } \\
\text { upgrading }\end{array}$ & $\begin{array}{l}\text { - An increase in buyer-producer relationship lead to global business } \\
\text { expansion } \\
\text { - An increase in suplier-producer relationship lead to efficient business } \\
\text { process. } \\
\text { - An increase in the interaction with buyer lead to upgrading technological } \\
\text { capability } \\
\text { - An increase in the knowledge about competitor lead to upgrading } \\
\text { technological capability }\end{array}$ & $\begin{array}{l}\text { Buyer-producer relationship } \\
\text { Supplier-producer relationship } \\
\text { Producer's knowledge on } \\
\text { competitor }\end{array}$ \\
\hline & D & $\begin{array}{l}\text { Diversified } \\
\text { Business }\end{array}$ & $\begin{array}{l}\text { Product } \\
\text { and process } \\
\text { upgrading }\end{array}$ & $\begin{array}{l}\text { - An increase in competition cause firm to diversify business and increase } \\
\text { innovate in logistic handling } \\
\text { - An increase in external knowledge flow cause to increase in product and } \\
\text { production process upgrading }\end{array}$ & $\begin{array}{l}\text { Producer's knowledge on } \\
\text { competitor }\end{array}$ \\
\hline & $\mathbf{E}$ & $\begin{array}{l}\text { Diversified } \\
\text { Business }\end{array}$ & $\begin{array}{l}\text { Product, } \\
\text { Process \& } \\
\text { intrachain } \\
\text { upgrading }\end{array}$ & $\begin{array}{l}\text { - Market demand on product quality requires firms to strictly apply product } \\
\text { ad process standardization } \\
\text { - An increase in competition causes firms to diversify business and increase } \\
\text { innovate in logistic handling. }\end{array}$ & $\begin{array}{l}\text { Buyer-producer relationship } \\
\text { Producer's knowledge on } \\
\text { competitor }\end{array}$ \\
\hline
\end{tabular}

Sources: reprocessed from Aminullah, et al. (2015), (2015a) 
diversification demanded by buyers (network upgrading). In supporting the intrachain upgrading, the firm has built 42 units of plants and has 25 branches in various business areas of seafood processing. With the capability of innovation and entrepreneurship, the firm has become one of the best sea food processing firms in East Java. The key success of the firm is maintaining the spirit of innovation by always positioning the firm in global competition pressures, therefore, the ideas of innovation for business expansion always arise periodically.

\section{Firm B}

Customer demand on product quality requires firm to strictly apply product ad process standardazation In meeting the customer demands, Firm B strictly practices hygienic processing under the supervision of the quality management system and HACCP. The firm processing plant has been certified by the BRC and ISO, two institutions that guarantee food safety standards for consumer products in Asia, Europe, and the US. The firm has also been accredited with many standard certificates such as the HACCP, GMP, ISO, BRC, and BAP/GAA.

A change in user's requirements lead to increase in product upgrading. Firm B's management decides product development and production process based on the customer demand. Customers generally request complete information with detailed specifications, including the design of packaging. Then, the R\&D unit, under the division of quality assurance, processes that idea into a product. Firm B uses the brand of importers that are known in the overseas market. The use of importer brands is intended to make Firm B's products easier to be accepted in the country of destination. Market demand for Firm B's products is higher than the capacity of the firm to supply to the importer that makes the firm survive with the existing products. As part of Company Group X, the firm has decided to specifically produce frozen shrimps and readyto-cook products. The production of other shrimp products have become the area of other firm members of Company Group X.
An increase in market demand for export causes the performance of intrachain upgrading. The firm's business expansion is a part of the organizational innovations of Company Group $\mathrm{X}$ that aims to develop Indonesian seafood products for the export market. The firm developed intrachain upgrading by increasing capacity and production cost efficiency. The firm built additional processing plants to increase production capacity. After establishing the first plant in East Java, the firm established another plant in South East Sulawesi by using raw materials in the island of Sulawesi. Currently, the firm has upgraded the freezing machine into two IQF machines to increase the storage capacity. The effort can be regarded as innovation management, especially to maintain supply continuity. In 2011, the firm expanded to crab business. The expansion was shown by establishing two plants in East Java and West Java for pasteurizing crab meat.

\section{Firm C}

An increase in material shortage leads to a shift toward alternative sources of material. Learning from past experiences of material shortage, the firm has now shifted the source of raw material from sea caught into mostly shrimp farming. Most of the shrimps are obtained from shrimp farming in Lampung. In 2005, the firm established its own shrimp ponds in Bangka Island. There is also a plan to build processing plants near the farms in order to minimize the transportation cost and maximize the shrimp freshness. As an export-oriented processing company, the firm sells its products to the US (60\%), Japan (30\%), and other countries $(10 \%)$. The US has been a favorite destination for shrimp export since Japan has experienced a decreasing economy in recent years.

A change in buyer's requirements leads to increases in product upgrading. The firm has been upgrading many aspects of its business, including product, process, and market. At the beginning, the firm produced only frozen raw shrimps. Through trial-and-error, the firm was then able to develop value-added processed shrimps. In developing various products, the firm is able to keep up with the increase in the 
standard of product quality as required by the buyers and the export-destination countries. Currently, the firm has attained the following certificates: HACCP, BRC, and BAP. By obtaining these certificates, the company is able to reach and maintain buyers' trust on product quality. The firm also upgraded its processing machines for frozen and value-added products. However, the firm only upgraded its technology of freezing machines after several years. Currently, the firm's top management regards the technology as lagging behind in comparison with competitors from other ASEAN firms.

\section{Firm $A$ "}

An increase in the buyer-producer relationship leads to global business expansion. The firm is born to be a global market player and very expansive company. It was grown as a small export's firm for Japanese market (specializing on dried anchovies), and expanded its business to be a seafood manufacturer, and now transformed into an integrative seafood company. The key is building a strong network relationship with buyers from local and international market and sharing knowledge to local suppliers. Currently, 500 suppliers work for the company, from only two suppliers in 1994.

An increase in the suplier-producer relationship lead to efficient business process. The suppliers deliver fish directly to the nearest mini plants (some plants were invested by the local suppliers and some by the firm) to be half-processed and then transported the products to the central plant. The firm assigned staff to help the local suppliers who are able to run the mini plants followed its standard. This is the company's way to keep the chain fresh and open jobs opportunity for rural area, as well as reducing labor operating cost.

An increase in the interaction with buyer lead to upgrading technological capability. Market or buyer information is the main source of knowledge for the firm in upgrading technological capability, The international buyers shared information to the company, not only the required products' types and standard requirements, but also evaluates and supervise its production practices to meet their standard. Involving global retail customers, such as Carrefour and Walmart, is another driven factor for the firm to innovate. The global retail chains set up the highest international standard for their suppliers.

An increase in the knowledge about competitors leads to upgrading technological capability. Competitors are another source of knowledge to innovate in company. Knowledge about competitors leads to upgrading technological capability by buying technology, both from importing and domestic sources, also as a strategy to upgrade its production capability. The technologies were combined and modified to suit their need. Despite increasing production capability, the conventional technology is still applied, for example sun drier and manual production.

\section{Firm D}

An increase in competition cause firm to diversfy business and increase innovation in logistic handling. Due to high competition, the firm does not focus only on tuna processing, as the unstable supply of tuna cause firm to expand into various seafood commodities and diversified the business by the end of 1996. In 1999, the firm built cold storage and bought fish vessels as well as transporter vessels to support its business. In order to secure plant and storage while optimally operates under the lack of supply, the firm imported raw fishes. Since 2011, the firm has also become a food logistics firm that provides modern logistic services including repacking, labelling, cargo service, and port documents.

An increase in external knowledge flows cause an increase in product and production process upgrading. The firm began its operation using a conventional cold storage, but then continually upgrade its technology through learning by interacting with technology suppliers. Visiting abroad, searching information from the internet and interacting with technology suppliers are major sources for the firm to explore business opportunities and upgrade production process, product diversification, and its managerial capability. The firm has advanced its warehouse system using robotic technology (automation and computerization) to upgrade production process. Product diversification and creating new market 
is a strategy to minimize risk of unstable supply of tuna. The firm upgrades with the most efficient technology in short space of time using labour and energy uses. Then, the firm upgrades its managerial capability by setting up his own production management system, modified from other system. For example, evaluating Indonesian' manual production system with Chinese, Thailand, Vietnamese system, and combine them with European automated system to improve production speed.

\section{Firm $E$}

The market demand on product quality require firm to strictly apply product ad process standardzation. The source of innovation, especially product innovation, comes primarily from international market and standards requirement such as North American, European and Asian standard. To upgrade its production capability, the firm had to import technology, since local machinery technology has not developed yet. The technology suppliers provide training for their employees and after sales service. The company's capacity to maintain the quality of their products is embedded in the quality of human resources as well as the required equipment and technology to do quality control (QC). Therefore, the firm conducts training, weekly briefing, and standard practices to improve employees' understanding on quality standard.

An increase in competition cause firm to diversfy business and increase innovation in logistic handling. The company's ability to compete in global market also depends on the company's logistics capacity supported by its own cold storages in Jakarta and Bali, and expanded by larger factory in the Jakarta's marine industrial complex. The firm has a plan in the near future to not expand yet into another added-value related industry as fish canning, as it focuses on production quantity.

\section{B. Firms growth}

\section{Aquaculture (shrimp)}

There are two cases of shrimp firms that grew steadily. Furthermore, one case originally grew, then declining toward stagnant. Shrimp firms that grew steadily were supported by the diversification of products to other fishery products with higher added value. The shrimp firm tends to decline toward stagnant, which only diversify shrimp products without diversifying into other fisheries products with higher added value.

'The firm's growth seems related to the diversification of the business, where diversification is certainly supported by the integrated knowledge flows within the firm's interaction with the market (buyer) and the interaction of firms with the sources of raw materials (suppliers). Stability in the firm's growth is susceptible to shrimp disease, quality, and quantity of raw materials obtained from suppliers. When company's interactions with suppliers are disrupted, it will bring a negative impact on the firm's interaction with market and lead to a decline in the firm's growth. In brief, interfirm match in knowledge flows in shrimp processing industry not only affects the firms capability upgrading, but also affects the business growth.

\section{Fish processing}

The growth of fish processing firms viewed from learning process, according to Aminullah et al. (2015a, Graph 2), can be categorized into three types: i) Global born directly, the firm born directly as trader for export market, then firm shifted from trader to producer for export market and had the ability to learn normally with less surprises and slowdown as global market players. It reached the capacity to have rapid growth as producer for export market in certain period. The firm experienced the normal growth as trader for export market at the beginning period then it is followed by the rapid developments as producer for export market. Now the firm is performing the capacity to pursue further growth; ii) Fast learned global, the firm started as a domestic trader and develop fast. In a very short period since its establishment, the firm achieved the capacity to switch from domestic trader into producer for export market. It is followed by rapid development as the producer for export market, then the company quickly shift toward a mature level, which is indicated by the capacity to pursue further growth become slowly; iii) Delay learned global company, the firm has the ability 
to learn gradually as a domestic trader, resulting in a certain of period achieving the capacity to switch from domestic trader into a producer for export market. The firm experienced a constantly slow growth as domestic trader in a longer time. Upon getting sufficient capacity and favourable condition, the firm follows a sudden shift to become producer for export market with fast growth. Now, the firm is on its high growth to pursue further development.

\section{INTERACTIVE LEARNING AND KNOWLEDGE FLOWS: CROSS CASES ANALYSIS}

Interactive learning through firms' interaction and knowledge flows in fishery industry involves two chains: i) knowledge flows and information feedback between firms and buyers and ii) knowledge flows and information feedback between firms and suppliers/farmers.

\section{A. Aquaculture (shrimp)}

The three firms of aquaculture, according to Aminullah et al. (2015b), showed that complementary knowledge flows exist among firms, buyers, and suppliers. The buyer provides information related to demand, standard, technical assistance, testing, and inspection. The firm realizes all the requirements set by the buyer. The firm provides information related to traceability, quality standard, advice, and solution. Then, the farmer of shrimp aquaculture realizes all the requirements defined by the firm.

The firm's interaction with the buyer determines the shrimp production process in which the firms pay attention to both product quality standards and quality of service. When these standards are met, the firms can maintain its competitiveness on the shrimp processing competition in the country and abroad. In meeting the market taste that changes as per time, the firms make changes, either in the process of production or management. Indirectly, the interaction with the market encourages the firms to innovate for upgrading.

Furthermore, the firm's interaction with the supplier/farmer helps in determining the firm's success and meeting product quality and safety standards. The traceability records provided by the suppliers help the firm maintain the quality of products ranging from farming, the distribution process, and processing. The standard refers to quality maintenance in applying traceability system. Good communication between firms and suppliers/famers is important in applying the traceability system. When the maintenance of traceability system is met, the firms can sell its products to buyers in the country and abroad. In other words, firm interaction with input sources needs stable relationship for firm growth.

Firms generally perform product upgrading. Shrimp processing firms can upgrade by moving into more value-added products. The example is by moving from IQF, prepared, cooked, readyto-cook, and ready-to-eat products to chemical residue-free products. Firms also work on process upgrading by transforming inputs into outputs more efficiently through modern technology or reorganizing the production systems. The example is by equipping logistic handling with register of traceability and cool chain system. Moreover, intrachain upgrading is performed by the successful firms on their product and process. Firms develop new linkages of the business system, such as market diversification, through product diversification demanded by buyer (network upgrading).

\section{B. Fish processing}

Knowledge flows among the three elements of upgrading (foreign buyer, local producer, and local supplier) will keep local firms increase within value chain, change into higher value chain; and promote product, process, and organizational innovation.

The firm's interaction with the buyer and supplier. The motivation of foreign buyer in transferring the knowledge to local producer is for the stability of products supplied by the firm. Similarly, local producer transfers knowledge and skill to local supplier to ensure the stability of fish commodities supply. The sufficiency of fishery resource availability is the limiting factors of fish commodities supply that decisively affect the stability of fish products supply. The instabil- 
ity of fish's commodities supply originating from over fishing as well as bad season for tuna fish and shrimp disease affect the growth dynamics of fish's processing firms.

Firms generally perform product upgrading. Innovation in the low-tech of fishery industries with the high standard of food safety and products differentiation were mostly driven by buyer-producer relationships. Firms mostly apply adaptive innovation or modify existing technology or knowledge, while modes innovation are generally user dominated innovation in creating new product for global market, which is conducted by large-scale fish processing firm.

Firms also perform process upgrading. Firms mostly applied three strategies, includes cost-cutting oriented innovation, business innovation, and managerial innovation. Firstly, cost cutting oriented innovation is firms' strategy to reduce high cost of fish processing due to high competition in securing fish supply for their processing plants, high risk transportation mode particularly from suppliers to the processing centers, and increasing labor cost. The companies applied efficient production management, such as raw material diversification, imported raw material, plants establishment near raw material supply, and logistics automation use. Innovation in logistics, such as cold storage, automated storage, advanced processing and packaging, and cold chains has reduced cost of logistic and raw material processing. Therefore, firms reduced production cost through establishing close networks with local and international suppliers or even with competitors or seafood international business networks.

Secondly, establishing new business or business innovation is another strategy for the firms to keep their business fully operated. For example, Firm A had difficulty in maintaining supply of raw material, hence the company decided to shift part of its business to be food logistics for other products instead of seafood. Meanwhile, Firm B established a specific production line for each export regions to minimise mixed-up standard and traceability of products. Firm $\mathrm{C}$ had a strategy to expand its storage capacity, therefore, they were not bothered by fluctuating supply. The advanced logistics technology becomes easier to access since it was supported by funding institution. The strong business networks had opened opportunity for fish processing companies to learn new production process. The uncertainty of raw material from local supplier motivates them to diversify its business.

Thirdly, experiencing new way of managing or management innovation includes marketing, logistic and service innovations. Marketing innovations had been done through managing partnership along the fish commodity chains. High competition between fish processing companies had driven fish companies to work closely with suppliers through supply chain management or through interlock collaboration under loose relationship. Managing a good partnership is an important strategy for company to ensure their partners committed to supply them continually. The company invested in its partnerships in terms of ice supply and training on production quality for the fish suppliers. The higher intensity of companies' relationship, the more committed of suppliers to work with them.

In logistic innovation, the three companies reduce seasonal supply and secure its quality either by expanding and/or applying more advanced technology. The available business and government networks had contributed to the company to improve its logistics technology. The other driver is information availability from technology suppliers on new technology. Other services innovation in fish processing companies engages innovation in providing service for customer. The delivery service was possible since logistics technology is available. The demand for logistics technology was also high due to market competition that had reduced production capacity of companies.

\section{INTERACTIVE LEARNING FOR UPGRADING AND GROWTH}

\section{A. Model of interactive learning}

With the reference to analytical framework, finally this study synthesizes the findings into building a model of the so-called interactive learning for upgrading and growth in fishery 


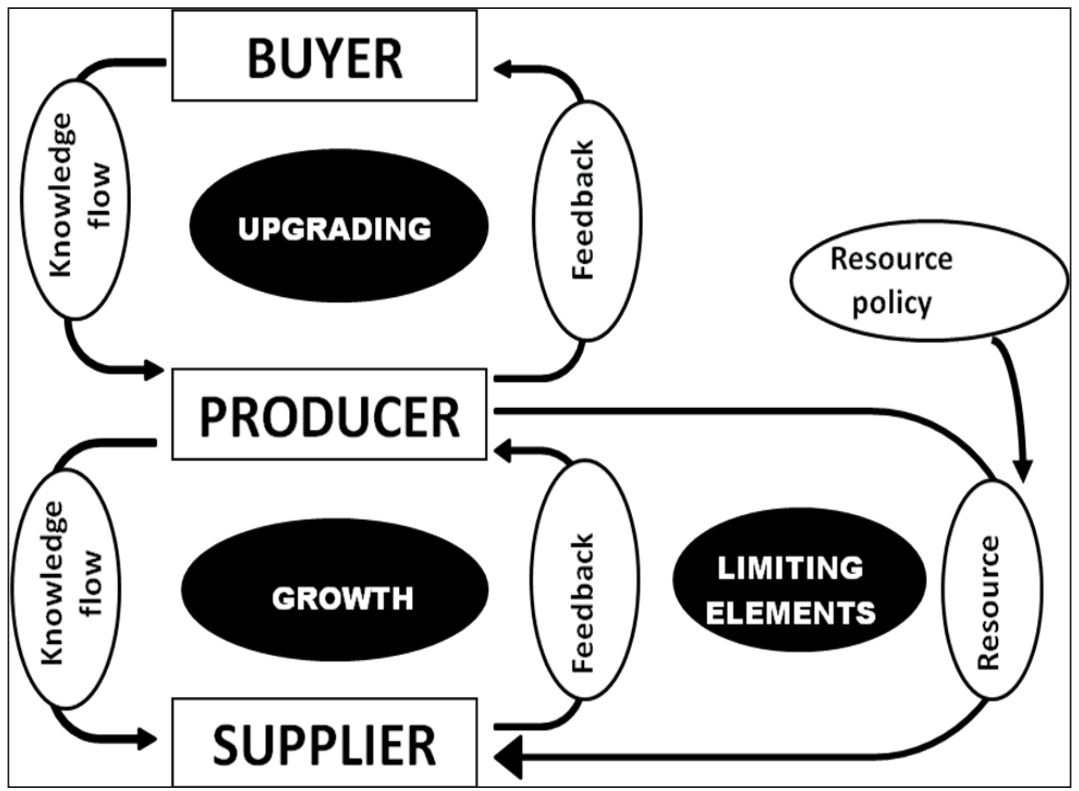

Figure 2. The Model of Interactive Learning for Upgrading and Growth

sector (Figure 2). The interactive learning through firms's interaction in knowledge flows work as a coupling of three loops in the global supply chain. The first loop is mutually enforcing local firms and foreign buyers in upgrading the capability of local firms. The second loop is mutually enforcing local firms and suppliers in the growth formation of local firms. The interfirm interactions contain knowledge flows and feedback in terms of information contents, specifications, and standard requirements among buyers, firms, and suppliers occur in a systemic supply chain. The third loop is the limiting elements of controlling the quantity and quality of resource supply that affect interfirm interaction. The elements are: i) the firm's growth is susceptible to shrimp disease, and ii) the sufficiency of fish commodities supply depends on resource availability which is affected by overfishing due to illegal fishing. This matter is subject to fishery resource policy enforced by the government. The model is a scientific contribution of this study. It needs further empirical evidence to be useful as a model of global supply chain in marine and fishery sector.

\section{B. Policy leverage}

Lessons learned from the above model for industrial and innovation policies are related to the leverage in easing the constraints of limiting elements. For aquaculture firms, those factors are preventing shrimp diseases and providing infrastructure, business facilities, and information, while for fishery firms those factor are illegal fishing, encouraging intercation with university, shifting to higher added value products, and institutional support for global trading.

Government could increase upgrading and growth in aquaculture (shrimp) firms by: i) preventing shrimp disease by supporting $R \& D$ activity to create the technology of making shrimp immune from disease; ii) building the infrastructure of aquaculture and ensure the supply of electricity to increase the shrimp supply, especially in the eastern part of Indonesia; iii) supporting R\&D on superior technology of shrimp varieties that are disease resistance or have a short harvest period; iv) meeting the high demand of modern frozen processing machines for shrimp processing industry, it is time for the Indonesian government to support frozen shrimp processing machine tools industry; v) provide information support on shrimp harvesting season, shrimp producers in other countries to facilitate firms to optimize its business plans to compete in the international market; vi) disseminate information regarding new product variety, new equipment, and new regulation to harmonize with information regulations and standards from the countries' international buyers (Aminullah, 2015b). 
Government could increase upgrading and growth in fish processing firm by: i) enforcing regulation on illegal fishing that have significant impact on increasing local fish production ${ }^{2}$; ii) facilitate firms' interaction with local universities or others STI centres; iii) encourage producer's firms to improve its competitiveness by shifting to higher added value fish products; iv) improving marine infrastructures for expanding the fish production throughout the country and; v) providing institutional support through various schemes of innovation and trade policies, namely: i. facilitate equipment procurement for capacity enhancement and quality improvement; ii. support accessing the export market and look for a suitable market to meet the needs of overseas buyers; and iii. lower the cost of production and trade as well as a conducive business environment that will spur the competitiveness of local firms and shifting into global market players (Aminullah, et al., 2015a).

\section{CONCLUSION AND POLICY IMPLICATIONS}

Interactive learning for upgrading and growth contain knowledge flows and feedback in local production network. The interactive learning through firms's interaction in knowledge flows work as a coupling of three loops: the upgrading capability, the growth formation, and limiting elements loops. The upgrading capability is limited by growth formation, which is determined by limiting elements. The limiting elements will control the quantity and quality of materials supply that affect interfirm interaction.

Policy implications from the model of interactive learning for upgrading and growth is that, industrial and innovation policies in fishery sector are related to the leverage in easing the constraints of limiting elements through: combating illegal fishing, encouraging interaction with university, shifting to higher added value products, institutional support for global trading, preventing

\footnotetext{
The significant impact of enforcing regulation on illegal fishing on increasing in fish production has been reported by Ministry of Marine Resource and Fishery. See KKP (2016).
}

shrimp disease, providing infrastructure, business facilities, and regulation information.

\section{REFERENCES}

Alam, N. S. M., \& Pokrant, B. (2009). Technological and organizational upgrading in the Bangladesh shrimp processing industry. Mediterranean aquaculture journal, 2(1),19-25. (http://dx.doi. org/10.21608/maj.2009.2666).

Aminullah, E., Fizzanty, T., Indraprahasta, G.S., \& Asmara, I.J. (2015a). Technological capability upgrading and entrepreneurship: Case study of selected Indonesian fish processing companies. STI Policy and Management, 1(1), 41-57. (http://dx.doi.org/10.14203/STIPM.2016.34).

Aminullah, E., Sari, K., Rahmaida, R., \& Soesanto, Q.M.B. (2015b). Firm's upgrading and growth through knowledge transfer: A case study of Indonesian shrimp processing firms. Project report on Firm-to-firm matching with technology transfers in the local and global economy: findings from Southeast Asia. Bangkok, ERIA Project 2014/2015.

Anh, P. T., Dieu, T.T.M., Moi, A.P.J., Kroeze, C. \& Bush, S.R. (2011). Towards eco-agro industrial cluster in aquatic production: the case of shrimp processing industry in Vietnam. Journal of cleaner production, 19, 2107-2118.

Aslesen, G. W. (1999). Governance and the innovation system of the fish-processing industry in Northern Norway (pp. 7-17). The STEP Report Series, No R-07.

Asmara, J. (2012). Penguatan zona ekonomi ekslusif dalam pengelolaan sumber daya maritim indonesia di wilayah perbatasan [Strengthening the ZEE in managing Indonesian marine resource at sea borders areas]. Jurnal Sosial Ekonomi Kelautan dan Perikanan, 2(2),131-144.

Brach, U. \& Kappel, R. (2009). Global value chains, technology transfer and local firms upgrading in non-OECD countries (pp.7, 13). Giga Working Papers, No. 110.

Caloghirou, Y., Constantelou, A., \& Vonortas, N. S. (2006). An operational framework for the study of knowledge flows. In Y. Caloghirou, A. Constantelou \& N. S. Vonortas (Eds.), Knowledge flows in European industry, pp. 67-69. London: Routledge.

Casson, M. (2010). Networks in economic and business history: A theoretical perspective. In $\mathrm{P}$. Fernandez Perez and M. B. Rose (eds), Innovation and entrepreneurial networks in Europe. Oxford: Routledge- Fundación BBVA, pp. 14-39. 
FIAS. (2006). Improving Indonesia's competitiveness: Case study of textile and farmed shrimp industries (p.14). Foreign Investment Advisory Service (FIAS), 1.

Fitrianto, A. R. (2012). Shrimp farmers' innovation in coping with the disaster (A case study in Sidoarjo mud vulcano disaster toward shrimp farmers responses. Precedia economics and finance, 4, 168-176. (https://doi.org/10.1016/ S2212-5671(12)00332-2).

Gereffi, G., Humphrey, J., Kaplinsky, R., \& Sturgeon, T. J. (2001). Introduction: Globalisation, value chains and development. IDS Bulletin, 32(3), 8.

Giusta, M. D. (2010). Entrepreneurial networks as social Capital. In M. Casson (Ed.), Entrepreneurship theory, networks, history, p.150. Cheltenham: Edward Elgar.

González-López, M. (2012). The Spanish cod fishing industry: Radical production changes without significant changes in the innovation system. Journal of Entrepreneurship, Management and Innovation (JEMI), 8(4), 35-51.

Ha, T. T. T., Bush, S.R., \& van Dijk, H. (2013). The cluster panacea? Questioning the role of cooperative shrimp aquaculture in Vietnam. Aquaculture, 388(39), 89-98.

Hajeb, P., \& Jinap, S. (2012). Fermented shrimp products as source of umami in Southeast Asia. Journal of Nutrition and Food Sciences, S10, $1-5$

Hatanaka, M. (2014). Standardized food governance? Reflection on the potential and limitations of chemical-free shrimp. Food policy, 45, 138-145. (https://doi.org/10.1016/j.foodpol.2013.04.013).

Humphrey, J. \& Schmitz, H. (2000). Governance and upgrading: Linking industrial cluster and global value chain research (pp. 12-13). Working Paper 120, Brighton: IDS.

Jeffs, A. (n.d). Development of innovation capabilities in the New Zealand seafood industry sector. Paper of National Institute of Water \& Atmospheric Research, Auckland.

Jespersen, K. S., Kellings, I., Ponte, S. \& Kruijsse, F. (2014). What shapes value chains, lessons from aquaculture in Asia. Food policy, 24, 228-240. (https://doi.org/10.1016/j.foodpol.2014.08.004).

Juarno, O., Oktaviani, R., Fauzi, A., \& Nuryartono, N. (2011). Kinerja produktivitas dan faktor yang berpengaruh terhadap total factor productivity (tfp) tambak udang Indonesia [Productivity performance and the factors of TFP on schrimp aquaculture in Indonesia]. Jurnal Sosial Ekonomik Kelautan dan Perikanan, 6(2),149-168.

KKP. (2016). Performance report of Ministry of Marine Resource and Fishery 2015. Jakarta: KKP.

Lebel, L., Munkung, R., Gheewala, S. H., \& Lebel, P. (2010). Innovation cycles, niches and sustainability in the shrimp aquaculture in industry in Thailand. Environmental Science \& Policy, 13, 291-302. (https://doi.org/10.1016/j. envsci.2010.03.005).

Machikita, T. \& Ueki, Y. (2012). Impact of production linkages on industrial upgrading in ASEAN, the PRC and India: Organizational evidence of global supply chain (p. 4). ADBI working paper Series, No. 399 (November). Tokyo: ADB Institute.

Malerba, F. (Ed.). (2004). Sectoral system innovation: Concepts, issues and analysis of six major sectors Europe (pp. 9-35). Cambridge: Cambridge University Press.

Malerba, F., and Sunil, M. (Eds.). (2009). Sectoral system innovation and production in developing countries: Actors, structure and evolution (pp. 3-22). Cheltenham: Edward Elgar.

Mets, T. (2012). Creative business model innovation for globalizing SMEs. In Thierry burgerHelmchen (Ed.), Entrepreneurship-creativity and innovative business models (pp. 169-187). Rijeka Croatia: Published by Intech.

Nicita A., Ognivtsev, V. \& Shirotori, M. (2013). Global supply chains: Trade and economic policies for developing countries (pp.1-3). Geneva: UNCTAD (Study Series No. 55).

Ponte, S., Kellings, I., Jespersen, K. S., \& Kruijsse, F. (2014). The blue revolution in Asia: Upgrading and governance in aquaculture value chains. World Development, 64, 52-64. (https://doi. org/10.1016/j.worlddev.2014.05.022).

Prusty, S.K., Pratap K. J., Mohapatra \& Mukherjee, C. K. (2014). System archetype to understand unintended behaviour in Indian shrimp industry and to aid in strategy development. System Practice Action Research, 27, 397-416. (https://doi.org/10.1007/s11213-013-9288-6).

Saptanto, S. (2011). Daya saing ekspor produk perikanan Indonesia di lingkup ASEAN dan ASEAN-China (Export competitiveness of Indonesian fishery products in ASEAN and China). Jurnal Sosial Ekonomi Kelautan dan Perikanan, 6(1), 51-60.

Sari, K., Arifin, M., Octaviyanti, D., Kusnandar, Syahbana, G. I. (2014). Sectoral innovation system 
in shrimp processing industry: case studies in East Java and South Sulawesi, Jakarta: Pappiptek LIPI, Research Report Series, 2014 (in Indonesian), pp. 31-44.

Sunoko, R. \& Huang, H-W. (2014). Indonesia tuna fisheries development and future strategy. Marine Policy, 43, 174-183.

Tran, Bailey, N. C., Wilson, N., \& Phillips, M. (2013). Governance of global value chains in response to food safety and certification standards: The case of shrimp from Vietnam. World Development, 45, 325-336. (https://doi.org/10.1016/j. worlddev.2013.01.025).

Truong, H., Lyne, M. \& Ford, K. W. (2014). Managing water pollution to revitalize the shrimp supply chain in Tam Giang Cau Hai Langon, Vietnam. UMK Procedia, 1, 50-56.
Vallejo, N., Hauselmann, P., \& Asante R. The role of supply chains in addressing the global seafood crisis. United Nations Environment Programme (UNEP) Report.

Van Duijn, A. P., Beukers, R., \& van der Pijl, W. (2012). The Indonesian seafood sector: $A$ value chain analysis (pp. 46-56). CBI Report. Netherlands.

Weerawardena, J., Mort, G. S., Liesch, P. W. \& Knight, G. (2007). Conceptualizing accelerated internationalization in the born global company: A dynamic capabilities perspective. Journal of World Business, 42, 301.

Widodo K.H, Perdana Y.R, \& Sumardjito, J. (2011). Product-relationship-matrix concept for marine and fishery supply chain model development. Jurnal Teknologi Pertanian, 12(2), 122-129.

\section{Firms' characteristics (Appendix)}

- Firm A/A" has operated since 1994 located in Gresik, East Java. The firm's ownership status is domestic investment. The firm is engaged in diversified business of processing fishery products, employment for approximately 14,000 workers, range of business such as fishing, processing anchovies, seafood processing, and frozen vegetable processing. The firm produces variety of fish

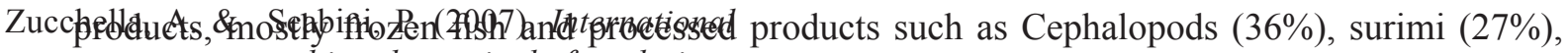
frozteristern and practices (pp. 128,129,133). New York:

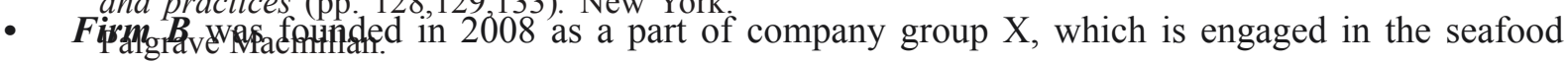
processing plant, exporter of frozen shrimp, and production of value-added shrimp products. Firm B has focused on the production and export of frozen shrimps, tuna, and octopus for meeting the demand of US market. For the Japan market, the firm only exports sea caught shrimps. The firm has approximately 400 workers, and 300 of them are permanent.

- Firm $\boldsymbol{C}$ was established in Jakarta in 1970. The firm is a pioneer of Indonesian shrimp processing industry. The firm has concentrated in producing frozen shrimps. The firm processes several types of shrimps: black tiger, Vannamei white, and sea-caught white, pink, and black shrimps. Currently, the firm is operated in Jakarta and Banjarmasin. The Jakarta plant processes most of the Vannamei white shrimps and also produces breaded items, while the plant in Banjarmasin mostly processes sea-caught shrimps in various sizes.

- Firm D was established in 1999 located in Jakarta's marine industrial complex, a leading fresh frozen tuna producers in Indonesia and employs over 400 workers. The firm does not only depend on one commodity, but expands to various sea-food commodities and diversified its business by the end of 1996. Currently the firm is the largest Indonesian importer of salmon from Norway.

- $\quad$ Firm $\boldsymbol{E}$ is a seafood processing firm, located in marine industrial complex, nearby Jakarta main port and is one of 5 largest companies in this area. The firm started the fishery business as the vessels owner in 1990s. Their current production capacity is approximately 13-15 containers per month and produces several fish products and sends its majority for export market. Europe holds as the biggest market for the company. As a former vessel's owner, the owner of firm $\mathrm{C}$ has a better knowledge in vessels operating business, even in fish capturing. 